\title{
Estádios Excludentes, Torcedores Invisíveis: Um estudo discursivo de comunidades de torcidas LGBTs no Facebook.
}

\section{Matheus S. Medeiros, Mónica Zoppi Fontana}

\begin{abstract}
Resumo
A partir do instrumental teórico da Análise do Discurso materialista desenvolvida por Pêcheux, em diálogo com os Estudos de Gênero, este trabalho retoma o conceito de lugar de enunciação em Zoppi-Fontana (2017) para analisar práticas discursivas de resistência inseridas no campo digital. Nosso corpus de análise é composto pela identidade visual e por um recorte de postagens das páginas Palmeiras Livre, Galo Queer, Queerlorado e Bambi Tricolor, coletivos de torcidas LGBTs no Facebook, que em tomadas de posição na modalidade de identificação elaborada por Pêcheux (1977) como contraidentificação, resistem e opõem-se às políticas do silêncio (ORLANDI, 2007) e aos sentidos dominantes sobre LGBTs, mulheres e negros no futebol. Esse posicionamento produz tensões em um espaço que historicamente construiu o homem cisgênero e heterossexual como seu interlocutor legítimo. Assim, analisamos demandas políticas de representação e de resistência, provenientes de lugares de interdição histórica, que abrem brechas discursivas e produzem deslocamentos de sentidos, a partir dos quais reivindicam legitimidade de outras formas de subjetivação. Em nosso percurso, refletimos ainda sobre os contradiscursos com os quais essas comunidades são confrontadas ao questionar uma ordem discursiva heteronormativa, a partir dos quais analisamos efeitos de evidência, preconceitos e silenciamentos.
\end{abstract}

\section{Palavras-chave:}

Análise do Discurso, Lugares de enunciação, práticas de resistência.

\section{Introdução}

Em nossa pesquisa, buscamos analisar os efeitos de processos históricos de exclusão e silenciamento da população LGBT a partir de discursos de (des)legitimação das comunidades de torcidas queer nas redes sociais, bem como descrever as disputas de sentido e os conflitos que se estabelecem em um nível discursivo nas publicações dessas comunidades. Da perspectiva teórico-analítica da Análise do Discurso materialista, entende-se que os sentidos que se produzem sobre determinado objeto não estão descolados da história e que os acontecimentos têm uma materialidade histórica, possibilitando a circulação de uma memória de sentidos.

\section{Resultados e Discussão}

O silenciamento de sujeitos LGBTs no futebol é materializado nos processos discursivos pelas evidências fornecidas por uma formação ideológica dominante. Essas evidências figuram em estereótipos discursivos sobre mulheres e LGBTs, cujos sentidos foram constituídos historicamente de efeitos negativos que justificassem uma posição de subalternidade.

Sendo assim, os dizeres são desiguais, uma vez que são determinados por divisões sociais e afetados por processos históricos de silenciamento. Isso configura a problemática abordada através da noção de lugar de enunciação. A circulação e a legitimidade dos dizeres estão determinados pela representação do lugar a partir de onde se diz.

Nosso corpus é composto por publicações e pela identidade visual das páginas LGBTs, que remetem a um mesmo campo discursivo, onde há embates entre formações discursivas. Na postagem da Palmeiras Livre a seguir, produz-se uma interdição sobre as palavras bicha, puta e macaco. Esses significantes, em sua historicidade, remetem a discursos homofóbicos, misóginos e racistas. Tais insultos produzem eco, inserindo-se em uma cadeia de já-ditos, em estreita conexão com formulações anteriores. A interdição constrói-se a partir de um movimento em que a página interpela o sujeito-leitor ao afirmar o que não deve e o que pode ser dito, desautorizando a circulação do sujeito em regiões de sentido relativos à intolerância.

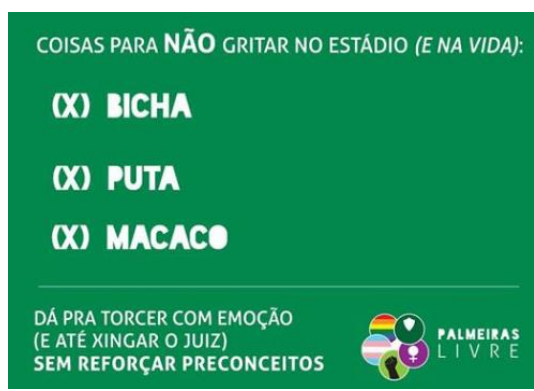

Figura 1. Postagem da Palmeiras Livre

\section{Conclusões}

Entendo as torcidas LGBTs de futebol como um engajamento desses sujeitos em práticas de resistência, que buscam transformar/atualizar os sentidos que constituem os estereótipos de que futebol não é lugar para LGBTs. Dessa forma, essas torcidas inscrevem, no interior do seu lugar enunciativo, demandas políticas de representação que fundam novos regimes de memória, a partir da construção de contradiscursos.

\section{Agradecimentos}

Agradeço ao CNPq pelo financiamento que viabilizou esta pesquisa.

\footnotetext{
Orlandi, E. P. As formas do silêncio: no movimento dos sentidos. $6^{\mathrm{a}}$ ed Campinas, SP: Unicamp, 2007.

2 Pêcheux, M. Semântica e discurso: uma crítica à afirmação do óbvio. $3^{\mathrm{a}} \mathrm{ed}$. Campinas, SP: Editora da Unicamp, 1997b.

3 Zoppi-Fontana, M. G. 'Lugar de fala': enunciação, subjetivação, resistência. Conexão Letras, v. 12, p. 63-71, 2017.
} 